\title{
THE ABUSE AND EXPLOITATION OF FOREIGN SEASONAL WORKERS: DID THE CORONAVIRUS EMERGENCY WORSEN ALREADY PRECARIOUS WORKING CONDITIONS IN THE AGRICULTURAL SECTOR?*
}

\author{
Karla Kotulovski, PhD Candidate, Teaching and Research Assistant \\ Faculty of Law University of Rijeka \\ Hahlić 6, 51000 Rijeka, Croatia \\ kkotulovs@pravri.hr
}

\author{
Sandra Laleta, PhD, Associate Professor \\ Faculty of Law University of Rijeka \\ Hahlić 6, 51000 Rijeka, Croatia \\ sandra.laleta@pravri.hr
}

\begin{abstract}
Seasonal workers are increasingly important in some Member States as a means to fill the labour market needs. Preferred due to their lower salaries, greater docility and the evasion of administrative and social security obligations, migrant workers are often treated less favourably than domestic workers in terms of employment rights, benefits and access to adequate housing. The agricultural sector of employment is particularly at risk of labour exploitation during harvest seasons and thus associated with atypical or informal forms of employment and precarious working conditions. The COVID-19 pandemic gave visibility to the new risks the seasonal workers are exposed to. In addition, it showed that in some cases such problems can lead to the further spreading of infectious diseases and increase the risk of COVID-19 clusters. The consequences of of the pandemic can be observed in Croatia too. This paper primarily covers the position of third-country nationals who enter and reside in Croatia for the purpose of agricultural seasonal work within the framework of the Seasonal Workers Directive (Directive 2014/36/EU). Significant challenges facing the Croatian labour market have been addressed
\end{abstract}

This paper is written under support of the University of Rijeka Research Project "Legal Aspects of Companies Restructuring and Transition Towards New Corporate Governance Culture" (uni-ridrustv-18-43) and under support of Project "MI - jučer, danas, sutra”, UP.04.2.1.06.0018. 
by means of a comparative approach in order to present the current situation on the EU labour market and suggest potential legal solutions applicable in regard to the national circumstances.

Keywords: seasonal work, third country nationals, Seasonal Workers Directive, agriculture, precariousness, Croatia, COVID-19

\section{SEASONAL EMPLOYMENT IN AGRICULTURAL SECTOR AS PRECARIOUS}

In the early 1960s, the Italian economist Sylos Labini articulated a basic definition of the concept of precarious employment by reference to agricultural work as a type of employment performed by workers with no guarantee of stability either of their job or of their income, and hence no definite prospect of improvement. ${ }^{1}$ The dominant understanding of neoliberal ideas and policies in the world of work aiming to restore the profitable growth has upheld these conditions. ${ }^{2}$

Mass media have reported various forms of discrimination related to the employment and exploitation of seasonal migrant workers with fatal outcomes in the areas of intensive agriculture within the EU, particularly in the Mediterranean countries that have begun to receive increasing attention. ${ }^{3}$ The failure of employers and governments to protect fundamental human rights has resulted in thousands of migrant workers and their families living in make-shift settlements; in housing made out of wooden pallets, cardboard and plastic from the local greenhouses with no legal protection and access to medical health. ${ }^{4}$

In general, workers in the agricultural sector are often victims of discrimination and disadvantaged in many aspects. Work deficits occur through job insecurity, low level of income, poor health, safety and environmental conditions, limited professional opportunities, high level of workplace accidents including pesticide poisoning ${ }^{5}$ and lack of access to the social security system.

Labini, S., Precarious Employment in Sicily, International Labor Review, Vol. 89, 1964, p. 268.

Harvey, D., A Brief History of Neoliberalism, Oxford, Oxford University Press, 2010.

3 Report on the situation at Manolada, 2020. [https://g2red.org/report-on-the-situation-at-manolada-july-2020], Accessed 2 February 2021. The message coming from Andalucia's strawberry fields was clear: You complain, you get fired. You're forced out of the EU. More: European Coordination Via Campesina, Sowing Injustice, Harvesting Despair, Spain, 2019, p. 2 (hereinafter: Sowing Injustice), [https://www.eurovia.org/wp-content/uploads/2019/11/EN2.1_lowres.pdf], Accessed 3 March 2021.

4 Covid19: Food \& vital supplies for migrant workers, [https://www.crowdfunder.co.uk/supportworkers], Accessed 5 February 2021.

5 For international standards protecting workers from exposure to agrochemicals see: ILO, The Safety and Health in Agriculture Convention (No. 184), 2001. 
Despite being the very heart of the food production system, agricultural workers experience the highest incidence of the working poor. ${ }^{6}$ Nonetheless, the agricultural sector has the lowest level of organization into trade union with an estimated less than 10 per cent of the world's waged agricultural workers represented in trade unions. ${ }^{7}$ The reduction of small agricultural businesses, intensification of production and monopoly of mass distribution make for a combined effect on the radical transformation of the agriculture areas. ${ }^{8}$ Regulated labour markets play the key role in determining employment and working conditions in rural areas. ${ }^{9}$ Producers are forced to search for flexible and low-cost labour often composed of foreign seasonal agricultural workers employed in extremely precarious conditions and exposed to high risk of exploitation. ${ }^{10}$ Therefore, agriculture has in many countries been transformed into an export-oriented sector heavily dependent on migrant labour.

As in other EU Member States, a shortage of seasonal workers is one of the key challenges of the Croatian agriculture. Domestic seasonal workers are employed based on the special employment contract, voucher, but it does not cover the actual demand for workers. In 201914190 seasonal workers performed work based on a voucher for 1530 employers in Croatia, with the average of 21.6 days of temporary work in agriculture. ${ }^{11}$ We should bear in mind that these numbers are even ( 4 or 5 times) bigger, because, alongside workers who perform work based on a voucher, are permanent seasonal workers employed on a fixed-term contract, as well as illegaly employed workers. Taking all this into account it is estimated that more than 50000 seasonal workers work in Croatian agriculture. ${ }^{12}$ The new

6 FAO, Sustainable Development Goals, 2015, [http://www.fao.org/sustainable-development-goals/ overview/fao-and-the-post-2015-development-agenda/sustainable-agriculture/en/], Accessed 2 February 2021.

7 ILO (2019), Decent and Productive Work in Agriculture, International Labour Office, Geneva, 2019, p. 3.

8 The Transformation of Agri-Food Systems, Globalization, Supply Chains and Small Holder Farmers, McCullough, E. B. et al. (eds.), The Food and Agriculture Organization of the United Nations and Earthscan, London, 2008, p. 28.

9 Martin, P. L., Migrant Labor in Agriculture: An International Comparison, International Migration Review, Vol. 19, No. 1, 1985, p. p. 137.

10 This so-called Californisation agricultural production system has become a structural feature in different EU Member States. The Californication model is based on four main elements: available workers, specific programs for the introduction of seasonal foreign workers, the spatial and social segregation of workers and the presence of labour intermediaries. See: Sowing injustice, op. cit., note 3, p. 3.

11 Smarter, Nezaposlene potrebno motivirati za sezonski rad u poljoprivredi, [https://smarter.hr/nezaposlene-potrebno-motivirati-za-sezonski-rad-u-poljoprivredi/], accessed 7 March 2021.

12 Smarter, op. cit., note 11. 
Aliens Act, ${ }^{13}$ in force as of January 2021, has introduced the labour market test as a requirement for the employment of third-country nationals in seasonal work, replacing the quota system of employment.

The paper first analyses the elements of precariousness of seasonal agricultural work. In the following sections focus is placed on different regulatory approaches to seasonal migrant work, especially the Directive 2014/36/EU of the European Parliament and of the Council of 26 February 2014 on the conditions of entry and stay of third-country nationals for the purpose of employment as seasonal workers. ${ }^{14}$ After a brief review of the Directive ratione materiae, the authors analyse the regulation of the employment of seasonal workers, working conditions, workers' rights and enforcement mechanisms, referring to the Directive. The authors address potential protective gaps, including the principle of equal treatment, with a critical overview of the extent to which the national regulatory framework is harmonized with the Directive. Finally, the paper deals with the pandemic COVID-19 and its impact on seasonal work in the agricultural sector.

\section{THE MANIFESTATION OF PRECARIOUSNESS OF SEASONAL (MIGRANT) WORK IN AGRICULTURE}

The contemporary concept of precariousness is identified in terms of high levels of labour insecurity and instability with broad implication on workers including their physical, mental and social well-being and the way in which they integrate paid work into other domains of social life. ${ }^{15}$ Just how important it is to recognize and combat precarious work in agriculture is evident from the statistics. Although its share in total employment has fallen from 40.2 per cent to 26.8 per cent over the past two decades, the agriculture sector provides livelihoods to more than one billion people worldwide accounting for 60.4 per cent of employment. ${ }^{16}$

Migrants, especially seasonal workers, face serious problem if hired through services of labour contractors specialized in recruitment, transport and management of waged agricultural workers creating a grey area around employers' responsibilities leading to general authority abuse. ${ }^{17}$

13 Zakon o strancima (Official Gazette No. 133/20).

14 Hereinafter: Seasonal Workers Directive, SWD.

15 Campbell, I.; Price, R. Precarious work and precarious workers: Towards an improved conceptualisation, The Economic and Labour Relations Review, Vol. 27, No. 3, 2016, p. 316.

16 ILOSTAT, Employment by sex and economic activity - ILO modelled estimates, November 2019.

17 For example: asking for commissions, overcharging for transport, housing and food, holding back wages etc. Seasonal workers are often employed through three main forms of labour intermediation schemes: government schemes for introducing foreign labour, private intermediation schemes (e.g. 
Wage agricultural workers ${ }^{18}$ performing seasonal activity are temporary workers employed for a limited period of time to perform a specific task; therefore, subjected to a high degree of insecurity. ${ }^{19}$ In practice, the temporary nature of seasonal worker permits/stay presents an obstacle to reaching the minimum threshold and minimum contribution periods required to access certain rights. ${ }^{20}$ Studies show the rise of casual forms of employment in agriculture. ${ }^{21}$ Considering the atypical nature of work and forms of employment in agriculture, including a surplus of seasonal workers in relation to the aggregated EU demand, the seasonal employment relationship makes the sector less accessible to regulate. In consequence, the European Commission expressed concerns regarding seasonal workers experiencing exploitation and substandard working conditions especially in the agriculture sector. $^{22}$

With the proclamation of the European Pillar of Social Rights in 2017 (EPSR), ${ }^{23}$ the institutional awareness concerning workers' equal treatment regardless of type and duration of their employment relationship was raised. EPSR presupposes fair working conditions and access to social protection for all workers emphasizing that employment relationships that lead to precarious working conditions must be prevented, including by prohibiting abuse of atypical contracts. It also notes that workers have the right to decent work and standard of living and transparent and predictable working conditions in keeping with the national practice. Finally, it highlights the right of workers to be informed in writing at the start of employment about all aspects of the employment relationship. However, growing evidence of migrants involved in highly insecure work experiences in agriculture

temporary employment agencies) and informal intermediation schemes. Mésini, M., Seasonal workers in Mediterranean agriculture Flexibility and insecurity in a sector under pressure, in: Thornley, C. et al. (eds.), Globalisation and precarious forms of production and employment: challenges for workers and union, Edward Elgar, Cheltenam UK, 2010, p. 60. Polish legislation does not allow a job intermediation agency to seek direct financial payment for a potential seasonal worker. However, it is allowed to seek payment for indirect services, like translation of the CV, the arranging of transportation or medical examination. Koroutchev, R., Seasonal Workers Before the Covid-19 Era: Analysis of the Legislation within the Context of Eastern Europe, Journal of Liberty and International Affairs, Vol. 6, No. 1, 2020, p. 107.

18 For categorisation see more: ILO (2007), Agricultural Workers and Their Contribution to Sustainable Agriculture and Rural Development, International Labour Office, Switzerland, 2007, p. 24-25.

$19 \operatorname{ILO}$ (2007), op. cit., note 18, p. 39.

20 ILO (2016), Non-standard forms of employment around the world, International Labour Office, Geneva, 2016, p. 298.

${ }_{21} \quad$ ILO (2019), op. cit., note 7, p. 4.

22 European Commission (hereinafter: EC), Migration and Home Affairs, [https://ec.europa.eu/ home-affairs/what-we-do/policies/legal-migration/work_en], Accessed 23April 2021.

23 EPSR, [https://eur-lex.europa.eu/legal-content/EN/TXT/?uri=CELEX\%3A32017C1213\%2801\%29], Accessed 12 January 2021. 
sets out a number of categories of risk factors that monitoring bodies took into account during interventions. ${ }^{24}$ The majority of EPSR principles tackling precarious employment in agriculture are being systematically violated. ${ }^{25}$

The question of precariousness can be observed in several segments including worker's personal situation (language and communication barriers for foreign worker); employers' behaviour (workers not being given a written contract and not being transparently and comprehensively informed of their rights, over-charging for transport, housing and food, holding back wages and imposing debt slavery); ${ }^{26}$ workplace organization and integration of worker in mostly rural economies they live in. ${ }^{27}$ Agricultural migrant workers are poorly protected due to the exclusion or limited application of the national labour legislation, ineffective investigations and low risk of prosecution for offenders. ${ }^{28}$

Using key legal determinants and indicators of precariousness, a vulnerable social position can be furthermore understood by means of a multidimensional approach which encompasses all manifestations of insecurity integrated in the employment and migration status of seasonal workers. ${ }^{29}$ Scholars conceive of an insecurity continuum presenting precariousness through: 1. pre-migration or work-divided precarity including individual circumstances of worker (poverty, family obligation, low education) and recruitment agency conditions; 2. migration (illegal traveling procedures deducting travel expenses from workers remuneration) and 3. destination country legal restrictions phase regarding rights and entitlements and

24 FRA, Protecting migrant workers from exploitation in the EU: boosting workplace inspections, 2018, p. 12-13.

25 La Via Campesina, Agricultural regions in Europe becoming no-rights zones for migrant workers, 2019; Agricultural workers' rights abuses in Spain, [https://www.ethicalconsumer.org/food-drink/agricultural-workers-rights-abuses-spain], Accessed 15 January 2021.

26 O'Connell Davidson, J., Troubling freedom: Migration, debt, and modern slavery, Migration Studies, Vol. 1, No. 2, 2013, p. 176-195. See also: Lewis, H. et al., Hyper-precarious lives: Migrants, work and forced labour in the Global North, Progress in Human Geography, Vol. 39, No. 5, 2015, p. 593.

27 There are multiple advantages for recruitment agency regarding secondary functions such as dormitory labour regimes. Dispositional workers in dormitory facilitates and just in-time production makes it easier to organize on-call work. However, how these advantages could be turned into abusive practices making possible for agencies to keep the workers under permanent and discreet control. See: ILO, Fair migration: Setting an ILO agenda, International Labour Office, Geneva, 2014, p. 15.

28 EC (2014), Communication from the Commission to the European Parliament and the Council on the application of Directive 2009/52/EC of 18 June 2009 providing for minimum standards on sanctions and measures against employers of illegally-staying third country nationals, COM (2014) 286 final, 22 May 2014.

29 Kountouris, N., The Legal Determinants of Precariousness in Personal Work Relations: A European Perspective, Comparative Labour Law \& Policy Journal, Vol. 34, No. 1, 2012, p. 23. See also: Zawojska, A., Exploitation of migrant labour force in the EU agriculture, Scientific Journals of the Warsaw University of Life Sciences, Economics and Organization of Food Economy, No. 116, 2016, p. 39. 
ocupational safety and health (OSH) standards, which can activate precariousness through insufficient or incorrect use of protective personal equipment, ${ }^{30}$ and lack of access to information resulting in the agricultural sector being the most affected by workplace accidents and illness, social isolation and workers multiple dependence on the employer (recruiter). ${ }^{31}$ Lack of the required language skills and social and professional networks in the host country usually prevents migrant worker from having full information about labour market opportunities and about their rights, and considerably lowers their bargaining power, thus activating administrative and socio-economic precariousness of workers. Besides trade unions, NGOs present an important actor in the dissemination of information on the rights of workers and complaint mechanisms available, field visits to workers, as well as counselling services. ${ }^{32}$ However, the premises of the employer in the agricultural sector are often located in rural area, making it difficult for the worker to leave, and for the NGOs and trade unions to inspect the premises. ${ }^{33}$

This needles to say calls for a holistic approach tackling wage precariousness in the agricultural sector in general, with income generally tending to be low (and sometimes not in the legal tender), not proportional to the number of hours worked and not periodically adjusted. As a result, many workers live below the poverty line. ${ }^{34}$ The income determinants for waged seasonal agricultural worker depend on the number of days worked and the wage level. The income gap between full-time wage earners and seasonal workers is even wider in countries where unemployment benefits, education and health care are not provided. Foreign workers are discriminated as they are frequently employed in lower and less attractive positions. ${ }^{35}$

30 According to Agricultural and Country Workers Union of Andalusia (SOC-SAT) workers are expected to perform work without proper protection whilst dangerous agrichemicals are being sprayed in the greenhouses. COVID-19 clusters and outbreaks in occupational settings in the EU/EEA and the UK, 2020, p. 6.

31 Lewis, op. cit., note 26, p. 589.

32 European Migration Network, Attracting and protecting the rights of seasonal workers in the $E U$ and the United Kingdom - Synthesis Report, Brussels, EMN, 2020, p. 28.

33 Rijken, C., Legal Approaches to Combating the Exploitation of Third-Country National Seasonal Workers, The International Journal of Comparative Labour Law and Industrial Relations, Vol. 31, No. 4, 2015, p. 443.

34 FRA, Protecting migrant workers from exploitation in the EU: workers' perspectives, 2019, p. 16-36.

35 Foreign workers' earnings on average are lower than Italians': generally, the gap is higher for non-EU $(-25 \%)$ than for EU citizens (-20\%). Interestingly, in agriculture the difference is deeper for EU citizens $(-12 \%)$ than for non-EU citizens (-7\%). Italian Ministry of Labour and Social Policies, 7 th Report on Foreign workers on Italian market of labour, 2017. 
As collective bargaining is weak in agriculture, the national minimum wage is an important means to protect the seasonal workers as the lowest paid workers. It should be emphasized that workers in non-standard forms of employment, like seasonal, tend to be less well reached by minimum wage policies, and thus at risk of income precariousness. ${ }^{36}$ Essential workers in the agriculture sector make the highest share of minimum wage earners. ${ }^{37}$ The national minimum wage for employees in general largely corresponds to the minimum wages of seasonal workers meaning no minimum gross salary is per se defined in regard to the seasonal worker. ${ }^{38}$ For countries without statutory minimum wages, minimum wages are implemented via collective bargaining agreements. The number of the latter agreements covering a given job category varies significantly from country to country. While some only have one agreement covering the whole sector, other countries, in particularly Italy, have up to 60 with regard to agricultural work. ${ }^{39}$

\section{APPROACHES TO ATTRACT AND REGULATE THE SEASONAL WORK OF MIGRANTS IN AGRICULTURE}

Seasonal agricultural work is a highly labour-intensive activity with peak season, often low-paid and physically demanding that therefore tends to be unappealing to the domestic population. ${ }^{40}$ The unattractiveness of agricultural work faces the EU with a structural need for seasonal workers, especially low-skilled and lowqualified. ${ }^{41}$ The European Commission estimates that more than 100000 seasonal workers from outside the EU come to the EU every year. ${ }^{42}$

36 Eurofound (2020), Minimum wages in 2020: Annual review, Minimum wages in the EU series, Publications Office of the European Union, Luxembourg, p. 1.

37 Eurofound (2020a), Minimum wages in 2020: Will COVID-19 derail the quest for fair pay?, 2020, [https://www.eurofound.europa.eu/hr/publications/blog/minimum-wages-in-2020-will-covid-19-derail-the-quest-for-fair-pay], Accessed 1 March 2021.

38 EMN, (2020), Attracting and protecting, op.cit., note 32, p. 8.

39 Eurofound, Living and Working in Italy, 2021, [https://www.eurofound.europa.eu/hr/country/italy], Accessed 11 January 2021; Coderoni, S. et al., Farms Employing Foreign Workers in Italy: An Anaysis with Census Micro Data, The German Journal of Agricultural Economics, Vol. 67, No. 3, 2018, p. 189.

40 Seasonal migrant workers are typically involved in the so-called "three D" jobs (dirty, dull, dangerous). Mendez, G., Caviedes, A., Labour Migration in Europe, Palgrave Macmillan, UK, 2010, p. 33.

41 In EU seasonal workers are generally engaged in non- or low-skilled sectors, such as in agriculture or tourism. EC, Commission Staff Working Document: Summary of Impact Assessment accompanying the proposal for a Directive of the European Parliament and of the Council on the conditions and entry of third-country nationals for the purpose of seasonal employment. COM (2010) 379 final, SEC (2010) 887', Brussels, p. 2, 8.

42 EC, Migration and Home Affairs, op. cit., note 22. 


\subsection{Residence and stay permits, labour market tests, quotas and temporary migration programs}

Most EU Member States consider seasonal workers from third countries as part of the overall migration policy. ${ }^{43}$ In line with admitting authorization, they use short-stay visas, work permits, long-stay visas and residence permits. ${ }^{44}$ Work permits and residence permits do not necessarily overlap in so far as residence permits for seasonal workers are issued for several years, whereas work permits are issued for the duration of the employment contract.

In Croatian law, a residence and work permit is a combined approval of temporary stay and work. It can be issued for a period of 90 days to up to six months. According to Eurostat data, in 2019 Croatia issued most permits for a validity of seven to nine months. ${ }^{45} \mathrm{~A}$ permit can be issued only if the Croatian Employment Service $^{46}$ gives a positive opinion about the employment of the third-country national, based on the results of the labour market test, an important legislative novelty, replacing the employment quotas. In many Member States, a labour market test is applied to seasonal workers. Its purpose is to determine whether the labour market situation justifies the employment of third-country nationals or whether job vacancies can be filled by domestic citizens, EU/EEA citizens or foreign citizens already available in the domestic labour market. ${ }^{47}$

The employer's conditions requested in the labour market test to be fulfilled concern: the educational level, the educational qualification, work experience and all other conditions requested by the employer (Art. 97 (3) of the AA). ${ }^{48}$ There is an important exception concerning seasonal workers in so far as in case of employment of seasonal workers in agriculture, forestry, catering industry and tourism in

\footnotetext{
$43 \quad$ EMN (2020), Attracting and protecting, op. cit., note 32, p. 8.

44 EMN (2020), Attracting and protecting, op. cit., note 32, p. 5.

45 Ibid., p. 6.

46 Its regional service or office; hereinafter: CES.

47 OECD, The Employment of Foreigners: Outlook and Issues in OECD Countries, 2001, p. 189.
}

48 The employer's obligation is to request a labour market test before submitting the application for a residence and work permit. The test is carried out by the CES office that has to check the unemployed records and implement the intermediation procedure with the aim of recruiting workers from the national labour market. The employment intermediation should be carried out if there are persons in the unemployed records who fulfil the employer's conditions. The CES office has to inform the employer about the labour market test results within 15 days from the request made by the employer. The employer may apply for the residence and work permit within 90 days from being notified about the positive labour market test results. The CES office should give its positive opinion needed for the issuing of residence and work permit if the prescribed conditions are met. It is important to note that the positive opinion should not be given if the employer has less than $1 / 4$ of the employed that have citizenship of the Republic of Croatia, EEA or Swiss Confederation (Arts. 97, 98 and 99). 
Croatia, the residence and work permit may be issued without the labour market test and the opinion of the CES for a period of up to 90 days during a calendar year.

Particular Member States link attraction of foreign workers in the agricultural sector through bilateral labour agreements signed with the issuing countries. Such strategies can include the elimination of employment quotas for non-EU country nationals. ${ }^{49}$ Quotas are usually established periodically once a year through an estimation based on trends in employment and unemployment rates and needs of the labour market. ${ }^{50}$

By responding to labour market needs and attracting seasonal workers, the Member States can facilitate the allowing of re-entry of seasonal workers from third countries who were previously admitted to the same Member State to encourage the circular movement of seasonal workers and to combat illegal migration. ${ }^{51}$ The advantage for these workers arising therefrom is the preferential treatment providing third-country nationals with benefits from this simplified and accelerated application procedure. ${ }^{52}$ As part of the migration policy, Member States collect information on the required experience, skills and language levels of non-EU seasonal workers when applying for a work permit. ${ }^{53}$

To fill shortages, the EU Member States have developed measures to attract migrant workers which include shorter and simplified procedures and cooperation with third countries. In recent years there has been an expansion of temporary migration programs (TMP) as an instrument and a lawful alternative to illegal migrations, ${ }^{54}$ enabling communication and transaction between the country of origin (domestic labour market) offering potential agricultural workers and the destination country demanding labour supply, respectively. ${ }^{55}$ For example, Ger-

49 EMN (2020), Attracting and protecting op. cit., note 32, p. 15.

50 Coderoni et al., op. cit., note 39, p. 189.

51 Rijken, op. cit., note 33, p. 444.

52 Afsar, N.; Antoons, J., Seasonal workers in Belgium, EMN, 2021, p. 19, [https://emnbelgium.be/sites/ default/files/publications/Seasonal_workers_standalone.pdf], Accessed 24 February 2021.

53 EMN, Attracting and protecting, Czech Republic, 2020, p. 16. [https://ec.europa.eu/home-affairs/ sites/default/files/06_czechrep_seasonal_workers_2020_en.pdf], Accessed 21 March 2021.

54 Undeclared work is more prevalent in the agricultural than in any other sectors of the economy. Higher levels of undeclared work are a result of intense cost pressure from the food processing industry and food retailers to whom agricultural producers supply most of their output. For more generic drivers of undeclared work see: Williams, C.; Horodnic, A., Tackling undeclared work in the agricultural sector, European Platform Undeclared Work, 2018.

55 For regulatory questions and dilemmas regarding TMP and good practice see: Bregiannis, F., The European Seasonal Workers Directive and Lessons from Outside Europe, Master Thesis, Tilburg University Law School, Tilburg, 2017, p. 4. 
many has concluded the first bilateral cooperation agreement with Georgia in $2020 .^{56}$

Indeed, several Member States have adopted simplified work arrangements. For example, in 2011 Romania introduced a regulation of day labour for the performance of "unskilled working activities of an occasional nature". Hungary regulates the so-called "simplified employment" for seasonal work in agriculture which eventually led to abuses and under-reporting of working activities. ${ }^{57}$ In order to combat informality, some European countries have adopted voucher-based work which presupposes performing a specific task or fixed-term assignment. With voucherbased work, an employer "acquires a voucher from a third party (generally a governmental authority) to be used as a payment for a service from a worker, rather than cash". ${ }^{58}$ The national regulation of voucher-based work also differs significantly with regard to the sectors in which their use is allowed. For example, the liberalized regulation of voucher-based work in Italy led to an expansion in their use, thereby questioning its effectiveness in combating undeclared work. ${ }^{59}$

In Croatia only domestic workers can perform seasonal work based on a special employment contract for performance of temporary, resp. casual seasonal work in agriculture (voucher). ${ }^{60}$ It should be concluded before the beginning of work, for every working day, by delivery and receipt of the voucher. The content and form of the contract is regulated by LMA and a special By-law. ${ }^{61}$ The worker should keep the contract with him/her. The price of voucher for 2021 amounts to 24.48 kuna (3.3 EUR per hour).

The employer is not required to keep evidence about workers in agriculture, or to deliver a record on wages to workers, as opposed to employers according to the La-

56 Lechner, C., Attracting and Protecting Seasonal Workers from Third Countries, German National Contact Point for the European Migration Network (EMN) Working Paper 89, Federal Office for Migration and Refugees, 2020, p. 5.

57 Also for tourism or casual work in other sectors. See: Labour Law and Employment in Hungary - 2021 Guide, [https://accace.com/labour-law-and-employment-in-hungary/], Accessed 2 February 2021.

58 ILO (2016a), Non-standard employment around the world: Understanding challenges, shaping prospects, International Labour Office, Geneva, 2016, p. 25-26; Eurofound (2015), New forms of employment, Eurofound, Dublin, 2015, p. 82.

59 Zilli, A., Linclusione sociale attraverso i voucher per prestazioni di lavoro accessorio, in Brollo, M.;Cester, C.; Menghini, L. (eds.), Legalità e rapporti di lavoro: Incentivi e sanzioni, Trieste, EUT, 2016. See also: Eurofound, Italy: New voucher-based work scheme provokes debate, 2017. [https://www.eurofound.europa.eu/publications/article/2017/italy-new-voucher-based-work-scheme-provokes-debate], Accessed 23 March 2021.

60 Zakon o tržištu rada (Labour Market Act; Official Gazette No. 118/18, 32/20; hereinafter: LMA).

${ }_{61}$ Pravilnik o sadržaju i obliku ugovora o sezonskom radu u poljoprivredi (Official Gazette No. 28/2019), Art. 2 (1). 
bour Act (Art. 7, By-law). The work of a seasonal worker in agriculture is limited to 90 days per calendar year and need not be continuous (LMA, Art. 79 (2-4)). The worker enjoys protection of rights in line with the LA. With the purpose of determining the insurance period in regard to seasonal work according to a special regulation, seasonal worker is obliged after the period of work in agriculture, and no later than the end of the calender year, to provide information about the work performed in agriculture in that calendar year to the body in charge of pension insurance.

The Croatian Employers Association made several proposals for more flexible use of vouchers, most notably that the worker who works based on a voucher can perform work for several years, until the maximum of 90 days is aggregated. ${ }^{62}$ Moreover, one of the options is to enable work on voucher also for workers who had an employment contract and persons in early retirement, which is at present not allowed.

\subsection{Seasonal Workers Directive}

An important regulatory mechanism at the EU level is the Seasonal Workers Directive. The adoption of this Directive was subject to a long and difficult process including the proposition of equal treatment for all migrant workers with the domicile workers, when approaching the issue of non-EU workforce sector by sector. ${ }^{63}$ The current version of the Seasonal Workers Directive represents an important development aiming to contribute to the proper management of migration flows as to the specific category of seasonal temporary ${ }^{64}$ immigration and to ensure decent working and living conditions for seasonal workers, by establishing fair and transparent rules on admission and residence (Preamble, under 7). ${ }^{65} \mathrm{In}$ other words, the Seasonal Workers Directive combines immigration law, which

62 Smarter, op. cit., note 11.

63 Zoeteweij, M. H., The Seasonal Workers Directive Another Vicious Circle? in: Rijken, C.; de Lange, T. (eds.), Towards a Decent Labour Market for Waged Migrants Workers, Amsterdam University Press, Amsterdam, 2018.

64 It should be noted that temporary work is out of the scope of this article as temporary agency works respect. workers are permanently employed by a temporary agency and sent to a second country or even to the same country to be utilised by the user enterprise. The same applies to posted workers. These categories are subject to specific EU legislation. See: Coderoni et al., op. cit., note 39, p. 192.

65 EU SWD was a first attempt to harmonise temporary labour migration among a number of states with divergent migration policy and proved a source of disagreement among Member States. Hooper, K.; Le Coz, C., Seasonal Worker Programmes in Europe - Promising practices and ongoing challenges, Migration Policy Institute, Brussels, 2020. 
regulates entry and stay for third-country national seasonal workers in the EU territory, with labour law, which governs the rights of workers. ${ }^{66}$

By virtue of Chapters II and III the Directive regulates the conditions for the admission and procedure and authorisations for the purpose of seasonal work. Furthermore, the Directive promotes temporary and circular migration, thus ensuring genuinely seasonal nature of work by limiting the maximum duration of the stay of seasonal workers to nine months in any 12-month period with some exceptions through possible extension of stay or renewal (Arts. 14 and 15).

Various preferences and policies related to specific economic circumstances of the Member States led to the emergance of a different personal status of third-country nationals within the Member States. ${ }^{67}$ The Directive demonstrates non-EU seasonal workers have a deficit of rights and more obligations in regard to the right to access and remain in different EU territories and socio-economic rights during their stay (Art. 22). Therefore, the Directive provides for equal treatment of seasonal workers and EU/EEA nationals in the nine categories listed in Article 23 (1) of the Directive (infra 4.1.).

Moreover, SWD provides standards relating to safe and adequate living conditions for the worker according to the national law and practice for the duration of his or her stay.

The Directive takes under consideration especially vulnerable situation of thirdcountry national seasonal workers and the temporary nature of their assignment. Accordingly, its provisions recognize the need to provide effective protection of their rights, including the matter of social security and monitoring compliance in respect for the principle of equal treatment with domicile workers (Preamble 43). In order to prevent abuse and violation of the workers' rights, SWD requires Member States to introduce complaints procedures and effective, proportionate and dissuasive sanctions against employers who breach their obligations under the Directive (Art. 17).

Employers are more likely to use national schemes including the abovementioned bilateral cooperation agreements. However, the latter should be based on the SWD. All aspects of the placement of agreements should comply with the protection of the rights of seasonal workers.

${ }_{66}$ Fudge, J.; Herzfeld Olsson, P., The EU Seasonal Workers Directive: When Immigration Controls Meet Labour Rights, European Journal of Migration and Law, Vol. 16, 2014, p. 440.

67 Medland, L., Misconceiving 'seasons' in global food systems: The case of the EU Seasonal Workers Directive, Euopean Law Journal, Vol. 23, No. 3-4, 2017, p. 160.

EMN (2020), Attracting and protecting, op. cit., note 32, p. 7. 
The final version of the Directive provided a broad flexibility to Member States concerning the admission structures; the duration of the worker's stay, and imposing or not the labour market test. The substantive provisions are designed so to ensure the equal treatment of seasonal migrant workers and national workers. Some aspects of the SWD concerning the rights of seasonal workers fall into the Member States' prerogative with individual adjustment leading to uneven practice on the national level. ${ }^{68}$ Nevertheless, the enforcement mechanisms provided by the Directive are discretional rather than mandatory. Therefore, its efficiency is questionable. ${ }^{69}$

\section{THE RIGHTS OF SEASONAL MIGRANT WORKERS IN AGRICULTURE}

\subsection{Right to equal treatment}

The aim of the Directive is to harmonize the entry of third-country nationals seeking temporary, seasonal employment in the EU and prevent their exploitation by granting them a secure legal status, equal working conditions and access to appropriate accommodation. ${ }^{70}$ Article 23 that regulates the right of equal treatment of the seasonal workers with the nationals of the host Member State in relation to specific issues is considered to be the core of the rights-based protection approach of the Directive. ${ }^{71}$

These categories are terms of employment and working conditions, the right to strike and take industrial action (in accordance with the host Member State's national law and practice), and freedom of association and affiliation and membership, the right to back payment of outstanding remuneration, the right to branches of social security as per Article 3 of Regulation 883/2004 (including sickness benefits, maternity benefits, invalidity benefits, survivors' benefits and family benefits), access to public goods and services, advice services on seasonal work offered by employment offices, education and vocational training, recognition of professional qualifications, and tax benefits (Art. 23).

Because of the temporary nature of the stay of seasonal workers, Member States will not be obliged to apply equal treatment on unemployment and family benefits, and may limit equal treatment on tax benefits and on education and vocational training (Art. 23 (2)). Member State's discretion right to set out optional

\footnotetext{
68 Ibid., p. 7.

69 Fudge; Herzfeld Olsson, op. cit., note 66, p. $463 \mathrm{ff}$.

70 Rijken, op. cit., note 33, p. 444, 446.

71 Fudge; Herzfeld Olsson, op. cit., note 66, p. 452.
} 
restrictions differs from no restrictions reported to explicit exclusion regarding access to family benefits with a similar legal approach considering seasonal workers entitlement to the unemployment benefits. ${ }^{72}$

Having regard to Art. 23 ( 1 and 2) of the SDW, the Croatian AA prescribes that seasonal workers have the same rights as Croatian citizens concerning the enumerated categories of rights (Art. 108 (1)). The level of rights depends on "the basis on which the conditions of seasonal workers will be equalized with those of national workers." 73 The Croatian legislator has made the Croatian regulations and collective bargaining agreements binding for the employer as a basis to equalize conditions.

Croatia has not used the possibility given by the Directive to restrict equal treatment of seasonal workers regarding certain rights, namely family benefits, unemployment benefits, ${ }^{74}$ education and vocational training, study and maintenance grants and loans, and tax benefits. Nevertheless, the question is whether a seasonal worker can fulfil the conditions needed for such rights/benefits. For instance, an unemployed person in Croatia can obtain the unemployment benefit if he/she was employed for nine months in the total period of 24 months prior to applying for such a benefit. On the other hand, the (equal) right of seasonal workers to education and vocational training is questionable, not only because of their temporary employment, but also because of the current inefficient regulation of the employer's duty to educate a worker. ${ }^{75}$

\subsection{Adequate accommodation}

In order to be admitted to work in the EU under the Directive, workers must accompany their application with evidence of adequate accommodation (Art. 5 (1) (c)). The benchmark of adequate living standards and most used indicators to

72 For right-based criticism towards the Council and the Member States for not extending the principle of equal treatment completely in case of third-country nationals see: Töttös, A., The Past, the Present and the Future of the Seasonal Workers Directive, Pécs Journal of International and European Law, Vol. 45, No. 1, 2014, p. 55-56.

73 Fudge; Herzfeld Olsson, op. cit., note 66, p. 457. Cf. Preamble, point 43.

74 However, they are entitled to receive statutory pensions under the conditions provided for by Art. 23.1 (2) of the Directive.

75 Laleta, S., Innovations and Growth of Skills: Challenges to the Croatian Legislature, Zbornik Pravnog fakulteta Sveučilišta u Rijeci, Vol. 39, No. 4 (Posebni broj), 2018, pp. 1860ff. There are examples of specific employment activity with employer that participate in continuing vocational training of its workers through specific contribution payment channel financing the training activities, whereby the seasonal worker benefits from an aggregation of hours for the completion of a training course. France and German Study, 2020, p. 25-26, p. 12. 
define minimum standards may vary among Member States. Most used criteria are sanitation, living space and safety. ${ }^{76}$ Where the accommodation is arranged by or through the employer, the Directive aims to protect seasonal workers and prohibits excessive rent that should not be automatically deducted from his or her wage (Art. 20). In some Member States, seasonal workers are being paid less than the minimum wage, as in-kind meals and accommodation is included. ${ }^{77}$

Pursuant to the Croatian Aliens Act, the ensured adequate accommodation should be "in accordance with the Croatian regulation and collective bargaining agreement that is binding for the employer". Under the AA, it is defined as "the accommodation enabling a seasonal worker adequate standard of living during the entire stay". In line with Art. 20 of SWD, the AA prescribes duties of the employer who has ensured the accommodation or who acts as an intermediator in ensuring the accommodation. He/she should not demand that the seasonal worker pays a rent that is too high compared with his/her net remuneration and with the quality of the accommodation. Such rent should not be automatically deducted from the wage of the seasonal worker. Likewise, the employer should submit the rental contract or an equivalent document in which the rental conditions for the accommodation are clearly stated, ensuring that the accommodation fulfils the general health and security norms in force in Croatia (Art. 104 (10) AA).$^{78}$ Seasonal worker and the employer should inform the police authority about any change of the accommodation within 8 days from the change.

Technical conditions for the adequate accommodation, the modus of rent payment and documentation are prescribed in the above mention By-law. Rental contract or an equivalent document are considered valid proofs of adequate accommodation. ${ }^{79}$ They should include the information on the rent amount, surface

76 EMN (2020), Attracting and protecting, op. cit., note 38, p. 23.

77 If the employer or landlord offers seasonal worker accommodation and meals it must be clearly regulated in the initial or in a separate contract. Provisions include the terms and conditions for the provision of the accommodation and deduction of a reasonable amount (Pfändungsfreigrenze) for the rent and meals from wages that does not expose seasonal worker at risk of being left without enough money left over each month to live on. Germany - important information for seasonal worker, 2020, [https:// www.arbeitsagentur.de/datei/important-information-for-seasonal-workers_ba146928.pdf], Accessed 11 January 2021.

78 The aim of the provisions is to protect workers from the employer's exploitation. Nevertheless, the Member States have the possibility to determine whether workers are free to arrange accommodation or if it is the employer's responsibility. See more: Fudge; Herzfeld Olsson, op. cit., note 66, p. 452.

79 The accommodation expenses should be appropriate to the amount of wage of the seasonal worker and should not exceed $30 \%$ of the net wage. If the employer ensures the accommodation to the seasonal worker without charge, he/she has to issue a document in which the conditions of the accommodation are clearly specified (Art. 28 (e)). 
and number of persons using the premises (Art. 28 (b)). The premises must satisfy certain conditions in order to be considered adequate. ${ }^{80}$

\section{THE PROTECTION OF INFRINGED RIGHTS OF THE SEASONAL WORKER}

The Directive prescribes the obligation of the Member States to ensure effective mechanisms through which the seasonal workers can protect their rights: a) directly, or b) through third party; or c) through a competent authority of the Member State (Art. 25). ${ }^{81}$ As already mentioned, third-country seasonal workers are particularly vulnerable. To be effective, a protective enforcement mechanism has to address all the aspects of the seasonal migrant workers' vulnerability. Therefore, a multi-faceted approach to enforcement is needed. First, in order to minimize the risks to which the workers who claim their rights are exposed, they should have the right to change employers, to claim obligations they would have been entitled to had the work authorisation not been withdrawn. Second, they should have the right of recourse against the principal contractor, what is especially important in the agricultural sector, where the labour supply chains are used. Third, the effective complaint mechanisms should be available to seasonal migrant workers, as well as the possibility that they engage a third party (e.g. a trade union representative or labour inspector) to submit a complaint on their behalf. Finally, an external monitoring mechanism should be available to ensure that the employers fulfil their duties under the Directive. ${ }^{82}$ The enforcement mechanisms are essential as a guarantee that migrant workers may enjoy labour standards provided for by the Directive. $^{83}$

$80 \quad$ It should be: a space in a fixed structure, with sanitary facilities that are physically separated from the living and sleeping premises; where running water, heating (except in an object where workers stay in summer) and electricity have been provided; which meets other health and hygienic living conditions, in line with special regulations (Art. 28.c). In the premises intended for living, sleeping and food preparation may be occupied by a maximum of six workers. The equipment and appliances at the premises may not be worn-out and damaged and they should be functional. The height of the rooms (from the floor to the ceiling) must enable free and safe movement of workers. Sleeping rooms for men and women should be physically separated, unless the seasonal workers are family members. Premises for the food preparation have to be positioned in such a way to allow individual food preparation. The minimum space for accommodation of a single seasonal worker has to be $14 \mathrm{~m}^{2}$ per person (including sleeping room, premises for food preparation and sanitary facilities); for 2 persons $20 \mathrm{~m}^{2}, 3$ persons 26 $\mathrm{m}^{2}, 4$ persons $32 \mathrm{~m}^{2}, 5$ persons $38 \mathrm{~m}^{2}$ and 6 persons $44 \mathrm{~m}^{2}$ (Art. 28 (d)).

81 Therefore, mechanisms through which seasonal workers may lodge complaints against their employers are under the Member States' powers, making their effectiveness dependant on national procedures (Art. 25).

82 Fudge; Herzfeld Olsson, op. cit., note 66, p. 459-460.

83 Fudge; Herzfeld Olsson, op. cit., note 66, p. 460. 
A seasonal worker who deems that some of his/her rights guaranteed by the Croatian Aliens Act have been infringed may, in order to protect and claim that right, initiate proceedings against the employer before the competent court, government authorities or legal entities with public authorities, in line with the Croatian legislation. The mentioned proceedings may be initiated even after the termination of his/her employment with the mentioned employer (Art. 109 (1-2)). Pursuant to the Labour Act, the procedure for the protection of worker's rights for nonfinancial claims consists of two phases; the first internal procedure run by the employer, and the second comprising judicial protection (Art. 133 (4) LA). The LA prescribes that a worker who has failed to duly initiate the proceedings with the employer may not seek judicial protection before the competent court, except in the case of worker's financial claim pertaining to the employment (Art. 133 (1-3)). Moreover, different rules of the LA apply to the protection of the worker's dignity. ${ }^{84}$

It is doubtful whether the described general protection of the worker's rights can actually be an effective mechanism for the protection of rights of seasonal migrant workers. Their work and stay in Croatia is of a temporary nature and seeking protection according to general labour law rules may become impossible due to the complexity and duration of the procedure, as well as its expenses. We should bear in mind that this is especially true for seasonal workers in agriculture who often perform work for very short periods, of up to 90 days in a calendar year. Therefore, it would be appropriate to provide special rules (de lege ferenda) introducing shorter procedures (and deadlines for claims) both with the employer and before the court, or to enable direct judicial protection without prior procedure run by the employer. Establishing a special body of public authority that would be in charge of workers' complaints would be more efficient.

The Croatian AA prescribes that in addition to persons entitled to the representation, other persons, associations and other authorized organizations entitled to give legal assistance, may take part in the procedure for the protection of worker's rights, based on the authorization given by a worker (Art. 109 (3 and 4) AA).

Trade unions are authorized to represent workers as their members. Furthermore, pursuant to Art. 434 (a) of the Civil Procedure Act, ${ }^{85}$ in labour-law court proceed-

84 See: Gović Penić, I. et al. (eds.), Priručnik o diskriminaciji i mobingu na radnom mjestu, Sindikat naftnog gospodarstva i Udruga za pomoć i edukaciju žrtava mobbing, Zagreb, 2018; Laleta, S.; Kotulovski, K., Mobbing and the protection of dignity in the Croatian legislation and practice: lex specialis as sine qua non?, in: Liber Memorialis Prof. Dr. Nada Bodiroga-Vukobrat, Hamburg, Verlag Dr. Kovač, 2021, p. 99-110.

85 Civil Procedure Act (Official Gazette No. 148/1, 25/13, 89/14, 70/19). 
ings a worker can be represented by a trade union's representative who is in an employment relationship with the respective trade union, of which the worker is a member, or in an employment relationship with the trade union association to which the respective trade union belongs. Since seasonal workers as temporary workers often perform work for up to three months, it is unlikely that they can easily join trade unions. The same is true if they stay in Croatia for up to six months (as a maximum). Therefore, it seems that third-country national seasonal workers will not seek the assistance of trade unions either in lodging complaints against the employer, or in a labour-law dispute before the court. In contrast, Austria has several contact points for seasonal workers that offer avenues for lodging complaints against their employers, including legislation specifically designating the Chambers of Agricultural Labour in this role and other institutions, such as trade unions and the Public Employment Service. ${ }^{86}$ What's more, in Austria organizations meeting the minimum treshold of employees can create representation bodies, i.e. work councils, which support employees in all work-related matters. ${ }^{87}$ As seasonal migrant workers become part of the employer's staff, their interests and rights should accordingly be protected by the work councils as the workers' participation body in Croatia.

In keeping with the Directive, the AA prohibits that a seasonal worker who has initiated the proceedings to protect his/her rights be put in an unfavourable position in relation to other workers employed by the employer, nor should this circumstance have an adverse effect on his/her rights arising from employment. As provided in Art. 117 of the LA, "an appeal or civil action, or participation in proceedings against the employer due to violation of laws, regulations or administrative provisions, collective bargaining agreement or working regulations, or the worker's approach to the competent state authorities shall not constitute a just cause for terminating the employment contract." The Labour Act prohibits any direct or indirect discrimination in the area of labour and working conditions, including the selection criteria and requirements for employment, advance in employment, professional guidance, education, training and retraining, in accordance with LA and special laws and regulations (anti-discrimination legislation).

One of the challenges connected with the protection of seasonal workers' rights is how to make information about such general protection rules (including the protection of worker's dignity and protection from being put in an unfavourable

\footnotetext{
86 Seasonal Workers from Third Countries in Austria, UN Migration, 2020, p. 26, [https://www.emn.at/ wp-content/uploads/2020/11/emn-national-report-2020-seasonal-workers-in-at.pdf], Accessed 17 April 2021.

87 EMN (2020), Attracting and protecting, op. cit., note 38, p. 27.
} 
situation) available to seasonal workers. They often do not speak the Croatian language, do not integrate easily in the working community by the employer, and, especially in agriculture, stay in rural areas where it is more difficult to get informed. In that respect, help could be provided by trade unions or other organizations (e.g. NGOs). ${ }^{88}$ The latter can also represent seasonal workers in the afore mentioned proceedings, in case they are authorized to provide legal assistance (Art. 109 (3 and 4) AA).

It is important to emphasize that, by virtue of the Directive, the application for the permit has to be accompanied by a valid work contract (or a binding job offer; Art $6(1(\mathrm{a}))^{89}$ and, what's more, the Directive prescribes the content of that contract. According to C. Rijken, such issues represent "objectified and standardized criteria that provide protection against exploitative practice $" .{ }^{90}$ It is important that a document which should accompany the application is legally enforceable. Together with the essential conditions that such a document should provide, it should guarantee the seasonal workers basic information about "what to expect and should give them a way to prove the conditions of employment in the event of a dispute." ${ }^{1}$

\section{SANCTIONS AGAINST EMPLOYERS}

\subsection{Liability to pay compensation}

Sanctions against employers who breach their obligations under the Directive should include liability of the employer to pay compensation to seasonal worker if the work authorisation is withdrawn for the following reasons: undeclared work and/or illegal employment, insolvency and breach of the obligations under the Directive, ${ }^{92}$ cancelling a full-time position in order to create vacancy that the employer is trying to fill with the migrant worker (within 12 months immediately

88 During field visits, an association of trade unions and NGOs in Germany that deals with seasonal work in the agricultural sector informs and advises seasonal workers of their rights and provides support in the event of labour law difficulties. Initiative Faire Landarbeit (2020) Saisonsarbeit in der Landwirtschaft NP. [https://www.pecoev.de/docs/InitiativeFaireLandarbeit_Bericht2020_IGBAU-neu.pdf], accessed on 13 January 2021

89 Cf. the Aliens Act: it is a "valid employment contract", that should be "in accordance with the Croatian regulation and collective bargaining agreement that is binding for the employer".

90 Rijken, op. cit., note 33, p. 446.

91 Fudge; Herzfeld Olsson, op. cit., note 66 p. 452.

92 Art. 9.2. of the Directive providing that Member State shall, if appropriate, withdraw the authorization. The meaning of terms "shall, if appropriate" is not clear, but it seems that a Member State has a discretion to determine the appropriateness of the certain grounds as a ground for the rejection of application or withdrawing of the work permit. Cf. Fudge; Herzfeld Olsson, op. cit., note 66, p. 455. 
preceding the date of the application), or violation of "labour law and working conditions". ${ }^{93}$ (Art. 17 (2), Directive). The employer's liability to pay compensation should be determined in accordance with the procedures under national law, and is hence not an automatic consequence of the imposed sanction. ${ }^{94}$

The Croatian AA under Art. 107 (6) prescribes the liability of the employer to pay compensation and all outstanding obligations in accordance with the provisions that regulate employment relations, if the residence and work permit was withdrawn. This sanction is prescribed for two instances when the permit may be withdrawn. First, if the employer does not fulfil the obligations regarding social security, worker's rights, working and employment conditions and tax duties, in line with the Croatian provisions and collective bargaining agreement binding for the employer. ${ }^{95}$ Second, when the bankruptcy or liquidation proceedings have been opened or the employer was under such proceedings, or when the employer does not perform an economic activity (Art. 107 (2)).

The Aliens Act refers to all outstanding obligations "in accordance with the provisions that regulate employment relations". It should be emphasized that according to the Directive, liability covers "any outstanding obligation which the employer would have to respect if the authorization for the purpose of seasonal work had not been withdrawn", i.e. legitimate expectations of seasonal migrants. ${ }^{96}$ A novelty of the AA is that the sanctions for and liability of the main contractor and any intermediate subcontractor is regulated as provided for by the Directive (Art. 107 (8 and 9) AA).

\subsection{Serious breach of employers' obligations}

Another novelty under Croatian law concerns the prohibition to issue the residence and work permit to an employer who, in the last one-year period, (at least)

93 Art. 9.3. (a), (b), (c) of the Directive providing that Member States may withdraw the authorization. See also: Fudge; Herzfeld Olsson, op. cit., note 66, p. 462.

94 Such a solution is criticized because seeking the compensation can be extremely difficult for victims of trafficking and in cases of labour exploitation. Rijken, op. cit., note 33, p. 449. These sanctioning provisions represent a mix of obligatory and optional clauses. Fudge; Herzfeld Olsson, op. cit., note 66, p. 462.

95 In Directive this is prescribed also as a possible ground for rejection of the application for authorization for the purpose of seasonal work (Art. 8 (4) point a). This measure seems to be effective and dissuasive. It seems that for the Croatian legislator this reason was not important enough to be prescribed as a reason to reject the permit. On the contrary, respecting equal treatment principle German Residence Act deals with less favourable terms for foreigners in relation to comparable German worker stating that approval can be revoked and seasonal work permit withdrawn in case same conditions have not been met. Residence Act (Aufenthaltsgesetz, AufenthG), s. 40.

96 Fudge; Herzfeld Olsson, op. cit., note 66, p. 463. 
twice failed to fulfil his obligations concerning social security, working conditions, etc. (Art.107 (7) AA). It seems that this sanction is not as effective and proportionate, as required by the Directive. To prevent such unlawful practice, the standdown period should be longer de lege ferenda and a blacklist of employers in breach should be published.

\section{EXTERNAL MONITORING MECHANISM}

The actors in place to ensure the protection of seasonal workers' rights include the Labour Inspectorate, state departments, regional and migration authorities including police and border guard services. Under specific circumstances, these actors are authorized to enter business premises and workplaces, request information and inspect documents. The SWD relies on national legislation regarding labour inspectorate's legal activity without additional enforcement policy obligations for the Member States, thus creating a protective gap (Art. 24). In countries with coordinated systems of social dialogue, minimum standards are regulated through collective bargaining agreements, with responsibility for monitoring and investigating breaches shared between employers and unions and labour inspectorates. ${ }^{97}$

According to the SWD, seasonal workers shall be entitled to equal treatment also with regard to health and safety requirements at the workplace which notionally protects workers against unsafe working conditions without mention of sanctions for employers who do not comply (Art. 23 (2)). In other words, Member States have to establish norms clearly defining the role of the executive agency as competent authority monitoring and enforcing compliance with OHS standards set to protect seasonal workers. For example, in Spain labour inspectors have a broad remit to monitor the physical working environment, including correct payment of wage rates set down in either law or collective agreements, along with employers' social contributions. ${ }^{98}$ Furthermore, the Labour Inspectorate in Spain on the indoor and outdoor workplaces advises public actors in the implementation of OHS measures regarding seasonal work. ${ }^{99}$

In Croatia, the Sector of Labour Inspection of the State Inspectorate is in charge of the monitoring of employment relations and OHS. Statistical data are rather scarce and not detailed, but according to available datasets, agriculture traditionaly belongs to sectors with high presence of illegal work. Illegal work is manifested

\footnotetext{
97 Grimshaw, D. et al., Reducing Precarious Work Protective gaps and the role of social dialogue in Europe, European Work and Employment Research Centre, University of Manchester, UK, 2017, p. 135.

98 EC, Muñoz de Bustillo Llorente, R.; Pinto Hernández, L. F., Reducing Precarious Work in Europe Through Social Dialogue: The Case of Spain, University of Salamanca, 2017, p. 35-38.

99 EMN (2020), Attracting and protecting, op. cit., note 38, p. 51.
} 
as employment or work of aliens in Croatia contrary to the law or without the mandatory application to the competent pension or health authorities. In $2017 \mathrm{a}$ total of 321 foreign workers ( 24 women) performed a job contrary to the Aliens Act's provision of the duty to obtain a work permit (compared to 140 aliens in 2016 and 97 in 2015). ${ }^{100}$

In 2020 inspectors established reasonable doubt that 232 aliens worked for employer contrary to the Aliens Act. Accordingly, they issued 50 decisions on the prohibition of performance of activity. The Ombudswoman received complaints of several aliens who claimed to had performed work without the permit and employment contract and/or the employer had not paid off their salary, while some of them, after having been dismissed, had no possibility to return to their home country (country of origin) because of the closed borders. ${ }^{101}$

\section{ASSESSING THE IMPACT OF THE COVID-19 ON AGRICULTURAL SECTOR - CONTINUED PRECARIOUS POSITION OF WORKERS IN THE POST-PANDEMIC PERIOD}

Seasonal workers in agricultural sector are already in precarious conditions in terms of employment, housing and social services, and discrimination owing to their status as migrants. Early research on the labour market consequences of COVID-19 indicates that the professions to be hurt the most are primarily the lowskilled and less-educated ones. ${ }^{102}$ In the context of Covid-19, Member States were called to ensure equal treatment regarding adequate protection from the coronavirus, and that health and safety of seasonal workers are safeguarded in transit and at the place of employment. ${ }^{103}$

However, the ongoing pandemic has aggravated the risk seasonal workers are exposed to and increased the possibility of Covid-19 infection. Many migrant seasonal workers in the agricultural sector have become stranded and unable to update their legal status, consequently facing situations of loss of employment and access to social benefits, including risk of being excluded from national vac-

100 Republika Hrvatska, Ministarstvo rada i mirovinskoga sustava, Inspektorat rada, Izvješće o radu Inspektorata rada u 2017. godini, Zagreb, ožujak 2018, p. 17.

101 Izvješće pučke pravobraniteljice za 2020., p. 47, [https://www.ombudsman.hr/hr/download/ izvjesce-pucke-pravobraniteljice-za-2020-godinu/?wpdmdl=10845\&refresh=608e7e957ab3e1619951253], Accessed 24 April 2021.

102 Adams-Prassl, A. et al., Inequality in the Impact of the Coronavirus Shock: Evidence from Real Time Surveys, IZA DP, No. 13183, 2020, p. 32-35.

103 European Parliament Resolution of 19 June 2020 on European protection of cross-border and seasonal workers in the context of the COVID-19 crisis, [https://www.europarl.europa.eu/doceo/document/ TA-9-2020-0176_EN.html], Accessed 1 March 2021. 
cination schemes. ${ }^{104}$ Workers in quarantined camps with no income, no social security and facing sanctions from the local government if they broke quarantine rules were afraid to report themselves sick and visit healthcare facilities. ${ }^{105}$ Several reports of Covid-19 outbreaks identified risk factors linked to essential workers while performing work including extreme long working days imposed, ${ }^{106}$ confined or close spaces with a lack of social distancing, sharing over-crowded transport and accommodation with poor hygiene conditions. ${ }^{107}$ Further analysis of following effect for the seasonal workers health and safety identifies sub-standard housing, ${ }^{108}$ additional financial costs and slowdown in production due to inexperienced labor force that needs to be adequately trained to work in agriculture incurred for the employers by the pandemic as a major challenge. ${ }^{109}$

Suggestions on activities to be undertaken at national or EU level to prevent reduction in job quality were concrete calling on Member States to assure adequate preventive and protective measures are in place and strengthen field inspections to ensure the proper application of OSH rules to seasonal workers. ${ }^{10}$ However, there are examples of practices for which supervision is unequipped to intervene. ${ }^{111} \mathrm{In}$ addition, interviews with farm workers and trade unions confirmed that language barrier continues to be a persisting challenge of migration in agricultural sector with labour contractors not providing clear information to seasonal workers on their rights and the legal recourse available to them. ${ }^{112}$

104 ILO (2020a), Seasonal Migrant Workers'Schemes: Rethinking Fundamental Principles and Mechanisms in light of COVID-19, International Labour Office, Geneva, 2020.

105 Neef, A., Legal and social protection for migrant farm workers: lessons from Covid19, Agriculture and Human Values, Vol. 37, No. 3, 2020, p. 641-642.

106 GüelL, B.; Garcés-Mascareñas, B., Agricultural seasonal workers in times of Covid-19 in Spain, ADMIGOV, 2020, p. 32.

107 Reports about performing work in slaughterhouses, meatpacking and distribution centers showed cramped working conditions resulting in high infection rates. Germany: 1,500 workers test positive for COVID-19 at meat-processing plant; company criticised for "failure" to protect workers, Business \& Human Rights Resource Centre, [https://www.business-humanrights.org/en/latest-news/germany1500-workers-test-positive-for-covid-19-at-meat-processing-plant-company-criticised-for-failure-toprotect-workers/], Accessed 1 March 2021.

108 Doomernik, J. et al., How (seasonal) agricultural demands for labour are met by immigrant workers in the Netherlands and Germany, ADMIGOV, 2020, p. 12-13.

109 EC, Kalantaryan, S. et al., Meeting labour demand in agriculture in times of COVID 19 pandemic, 2020, p. 6.

110 European Labour Authority, Safeguarding seasonal workers' rights: European Labour Authority takes action, 2019, [https://www.ela.europa.eu/news/safeguarding-seasonal-workers-rights-european-labour-authority-takes-action], Accessed 6 December 2020.

111 Doomernik et al., op. cit., note 143, p. 16.

112 Purkayastha et al., Work, health and Covid19: a literature review, ETUI, Brussels, 2020, p. 25-26. 
In Croatia, as a major food importer, the Covid-19 pandemic has triggered a desirable self-sufficiency model regarding the agricultural sector. ${ }^{113}$ As mentioned above, Croatia relies on foreign seasonal workers. The proposal of the simplification of the employment of (seasonal) workers in agriculture and the procedure of issuing permits is one of the goals of the Croatian agriculture strategy 2030. ${ }^{114}$

In the context of labour relations, the employer and the employee are obliged to adhere to the normative framework and to perform their contractual obligations as in regular circumstances. ${ }^{115}$ The coronavirus pandemic has made it much more difficult to pursue transparent and inclusive labor policies. ${ }^{116}$ Transparency was sometimes mixed with confusion concerning the legal procedures on how measures should be enforced. Specific health protection and OSH measures that were introduced regarding Covid-19 must apply to seasonal migrant workers, ${ }^{117}$ who should enjoy the same rights as the national workers. ${ }^{118}$

Given that the COVID-19 infection poses a direct risk to the safety and health of persons, it is worth mentioning the provisions of the OHS Act, under which both parties to the employment relationship are obliged to inform each other about potential health and life hazards. ${ }^{119}$ In this sense, the employer is obliged to inform the employee about changes that could affect his safety and health (Article 32 (1)) and the obligation of the employee is to inform the employer about the circum-

113 Croatian Chamber of Commerce. [https://www.hgk.hr/vanjskotrgovinski-deficit-poljoprivrednih-i-prehrambenih-proizvoda-smanjen-za-315-posto], Accessed 18 October 2020.

114 Nacrt prijedloga Strategije poljoprivrede do 2030., [https://poljoprivreda.gov.hr/UserDocsImages/dokumenti/Strategija_poljoprivrede_2020_2030/Strategija_poljoprivrede_do_2030..pdf], Accessed 2 May 2021.

115 Vidas, I., Pravni aspekt ograničenja prava radnika u slučaju pandemije s posebnim naglaskom na prava $i$ obveze poslodavaca $i$ radnika, IUS-INFO, 86/2020, [https://www.iusinfo.hr/aktualno/u-sredistu/41010], Accessed 3 May 2021.

116 For examples see: EU Agency for Fundamental Rights, Coronavirus COVID-19 outbreak in the EU Fundamental Rights Implications, 2020, p. 5,[https://fra.europa.eu/sites/default/files/fra_uploads/malta-report-covid-19-april-2020_en.pdf], Accessed 11 July 2020.

117 The Croatian Compulsory Health Insurance Act prescribes compensation for temporary incapacity for work or incapacity for persons (insured persons) who have received a medically indicated measure of compulsory self-isolation at home or ordered quarantine by the competent health institution. Art. 39 (3). Zakon o obveznom zdravstvenom osiguranju (Official Gazette No. 80/13, 137/13 i 89/19); Hrvatski zavod za zdravstveno osiguranje, Prava osiguranika na privremenu nesposobnost za rad zbog pojave koronavirusa, [https://www.hzzo.hr/en/prava-osiguranika-na-privremenu-nesposobnost-za-rad-zbog-pojave-koronavirusa-2019ncov/], Accessed 11 April 2021.

118 It must be underlined that in Croatia, the population takes their constitutional right to health care seriously (Constitution, Article 59) and deems it as a fundamental right. Denial of health care could also be deemed as a criminal offence as prescribed in the Croatian Criminal Code.

119 Zakona o zaštiti na radu (Official Gazette No. 71/14, 118/14, 154/14 , 94/18, 96/18). 
stances of the possibility of spreading the COVID-19 virus, which corresponds to Art. 68 (2). ${ }^{120}$

Extraordinary circumstances can disrupt or burden the business of the employer who in that case may (justifiably) terminate the employee's employment contract (Art. 122 LA). Considering termination of employment relationship as ultima ratio, the employer has at his disposal the legal institution of dismissal with the offer of alternative employment (Art. $123 \mathrm{LA}$ ) that prohibits the employer to make unilateral changes to the working conditions. In order to preserve jobs and implement measures to protect people against the spread of the virus, the employer may introduce alternative solutions including redistribution of working time (Art. 67 LA), shift work (Art. 71. LA), change the patterns of working time (Art. 66) or contract part-time work. Likewise, employers have the option to send workers on annual or paid leave. It is important to emphasize that in these situations, workers are entitled to a salary compensation. ${ }^{121}$

Concerning the active labour market policy measures, so far there have been no special measures for the employers utilizing the work of seasonal migrant workers. However, in the category Particularly Vulnerable Workers, the right to financial assistance for the so-called permanent seasonal workers was introduced. ${ }^{122}$ In addition, the Government's Job preservation subsidy applies to the agricultural sector. ${ }^{123}$ The subsidy amount is determined by a decline in revenue of at least $60 \%$ to qualify for the maximum subsidy of HRK 4,000.00 per employee which corresponds to the Croatian employer association requirements proposing compensation for seasonal workers in the agriculture sector under the same conditions as for other activities. ${ }^{124}$ The employer is obliged to retain all employees, meaning that dismissal is not permitted. However, if the employment contract is terminated, the employer is entitled to the subsidy payment for the days on which the employee worked until the employment contract was terminated.

120 Grgurev, I., COVID-19 and Labour Law: Croatia, Italian Labour Law e-Journal Special Issue 1, Vol. 13.

121 Vidas, op. cit., note 154.

122 Vlada Republike Hrvatske, Službena stranica Vlade za pravodobne i točne informacije o koronavirusu, [https://www.koronavirus.hr/rezultatipretrazivanja/20?q=vladine+mjere\#gsc.tab=0\&gsc.q=vladine\%20mjere\&gsc.page=1], Accessed 25 April 2021.

123 New measures to preserve jobs in Croatia COVID, [https://www.cms-lawnow.com/ealerts/2020/10/ new-measures-to-preserve-jobs-in-croatia?cc_lang=en], Accessed 25 April 2021.

124 Info za clanove HUP-a: Isplate potpore HZZ-a za travanj i svibanj, [https://www.hup.hr/info-za-clanove-hup-a-isplate-potpore-hzz-a-za-travanj-i-svibanj.aspx], Accessed 28 April 2021. 


\section{CONCLUSION}

Seasonal third country workers represent an especially vulnerable category of waged agricultural workers due to the presence of all the dimensions of precariousness. The Seasonal Workers Directive combines immigration law with labour law, that governs the rights of migrant workers. It embodies the approach of equal treatment of the seasonal migrant workers and domestic workers of the host Member State. Since the extent of the protection they actually enjoy depends on the terms and conditions that are guaranteed to national workers and the enforcement mechanisms available to seasonal workers, its efficiency is doubtful.

The New Croatian Aliens Act has brought an important novelty, namely the shift from the quotas to the labour market test system. Seasonal migrant workers are provided the same rights as the Croatian citizens concerning terms of employment and working conditions, and the protection of rights arising from the employment relationship. Croatian regulations and collective bargaining agreements that are binding for the employer are used as the basis to equalize conditions. On the flip side of the equal-treatment-coin, the general rules on protection in case of infringed rights do not represent effective and protective enforcement mechanism that is requested by the Directive. An appropriate, protective mechanism, tailored to fit the specific, temporary and precarious position of seasonal migrant workers, is needed de lege ferenda to bridge the present legislative gaps. The role of the labour inspection in this regard is crucial.

The Covid-19 pandemic has worsened working and living conditions in general. Seasonal migrant workers are facing new risks concerning the substandard accommodation with poor hygiene conditions and exacerbated free movement. In order to improve protection for migrant agricultural workers, they should be provided avenues for increased proactive inspections, anonymous reporting, alternative housing/employment and adequate workplace injury assessments in the healthcare system. For this reason, it is necessary to ensure effective and comprehensive regulatory framework with a policy promoting decent working conditions, productivity and income of waged agricultural workers.

\section{REFERENCES}

\section{BOOKS AND ARTICLES}

1. Adams-Prassl, A. et al., Inequality in the Impact of the Coronavirus Shock: Evidence from Real Time Surveys, IZA DP, No. 13183, 2020

2. Bregiannis, F., The European Seasonal Workers Directive and Lessons from Outside Europe, Master Thesis, Tilburg University Law School, Tilburg, 2017 
3. Campbell, I.; Price, R., Precarious work and precarious workers: Towards an improved conceptualisation, The Economic and Labour Relations Review, Vol. 27, No. 3, 2016, pp 314-332

4. Coderoni, S. et al., Farms Employing Foreign Workers in Italy: An Anaysis with Census Micro Data, The German Journal of Agricultural Economics, Vol. 67, No. 3, 2018, p. 185-202

5. Doomernik, J. et al., How (seasonal) agricultural demands for labour are met by immigrant workers in the Netherlands and Germany, ADMIGOV, 2020

6. Eurofound (2020), Minimum wages in 2020: Annual review, Minimum wages in the EU series, Publications Office of the European Union, Luxembourg, 2020

7. Eurofound (2020a), Minimum wages in 2020: Will COVID-19 derail the quest for fair pay? Publications Office of the European Union, Luxembourg, 2020

8. Eurofound (2015), New forms of employment, Eurofound, Dublin, 2015

9. FRA, Protecting migrant workers from exploitation in the EU: workers' perspectives, Publications Office of the European Union, Luxembourg, 2019

10. FRA, Protecting migrant workers from exploitation in the EU: boosting workplace inspections, European Union Agency for Fundamental Rights, 2018

11. Fudge, J.; Herzfeld Olsson, P., The EU Seasonal Workers Directive: When Immigration Controls Meet Labour Rights, European Journal of Migration and Law, Vol. 16, 2014, pp 439-466

12. Gović Penić, I. et al. (eds.), Priručnik o diskriminaciji i mobingu na radnom mjestu, Sindikat naftnog gospodarstva i Udruga za pomoć i edukaciju žrtava mobbing, Zagreb, 2018

13. Grgurev, I., COVID-19 and Labour Law: Croatia, Italian Labour Law e-Journal Special Issue 1, Vol. 13, pp $1-5$

14. Grimshaw, D., et al., Reducing Precarious Work Protective gaps and the role of social dialogue in Europe, European Work and Employment Research Centre, University of Manchester, UK, 2017

15. Güeil, B.; Garcés-Mascareñas, B., Agricultural seasonal workers in times of Covid-19 in Spain, Advancing Alternative Migration Governance, 2020

16. Harvey, D., A Brief History of Neoliberalism, Oxford, Oxford University Press, 2010

17. Hooper, K.; Le Coz, C., Seasonal Worker Programmes in Europe - Promising practices and ongoing challenges, Migration Policy Institute, Brussels, 2020

18. Italian Ministry of Labour And Social Policies, 7th Report on Foreign workers on Italian market of labour, 2017

19. Koroutchev, R., Seasonal Workers Before the Covid-19 Era: Analysis of The Legislation Within the Context of Eastern Europe, Journal of Liberty and International Affairs, Vol. 6, No. 1, 2020, pp 100-111

20. Kountouris, N., The Legal Determinants of Precariousness in Personal Work Relations: A European Perspective, Comparative Labour Law \& Policy Journal, Vol. 34, No. 1, 2012, 21-47

21. La Via Campesina, Agricultural regions in Europe becoming no-rights zones for migrant workers, 2019

22. Labini, S., Precarious Employment in Sicily, International Labor Review, Vol. 89,1964, 270271 
23. Laleta, S., Innovations and Growth of Skills: Challenges to the Croatian Legislature, Zbornik Pravnog fakulteta Sveučilišta u Rijeci, Vol. 39, No. 4 (Posebni broj), 2018, p. 1851-1880

24. Laleta, S.; Kotulovski, K., Mobbing and the protection of dignity in the Croatian legislation and practice: lex specialis as sine qua non?, in: Liber Memorialis Prof. Dr. Nada BodirogaVukobrat, Hamburg, Verlag Dr. Kovač, 2021, pp. 99-110

25. Lechner, C., Attracting and Protecting Seasonal Workers from Third Countries, German National Contact Point, Federal Office for Migration and Refugees, No. 89, 2020

26. Lewis, H. et al., Hyper-precarious lives: Migrants, work and forced labour in the Global North, Progress in Human Geography, Vol. 39, No. 5, 2015, pp. 580-600

27. Martin, P. L., Migrant Labor in Agriculture: An International Comparison, International Migration Review, Vol. 19, No. 1, 1985, pp. 135-143.

28. Medland, L., Misconceiving 'seasons' in global food systems: The case of the EU Seasonal Workers Directive, European Law Journal, Vol. 23, No. 3-4, 2017, p. 157-171

29. Mésini, M., Seasonal workers in Mediterranean agriculture Flexibility and insecurity in a sector under pressure, in: Thornley, C. et al. (eds.), Globalisation and precarious forms of production and employment: challenges for workers and union, Edward Elgar, Cheltenam UK, 2010, p. $98-113$

30. Mendez, G.; Caviedes, A., Labour Migration in Europe, Palgrave Macmillan UK, 2010

31. Neef, A., Legal and social protection for migrant farm workers: lessons from Covid19, Agriculture and Human Values, Vol. 37, No. 3, 2020, p. 641-642

32. O'Connell Davidson, J., Troubling freedom: Migration, debt, and modern slavery, Migration Studies, Vol. 1, No. 2, 2013, 176-195

33. OECD, The Employment of Foreigners: Outlook and Issues in OECD Countries, 2001

34. Rijken, C., Legal Approaches to Combating the Exploitation of Third-Country National Seasonal Workers, The International Journal of Comparative Labour Law and Industrial Relations, vol. 31, no. 4, 2015, pp 431-452

35. COVID-19 clusters and outbreaks in occupational settings in the EU/EEA and the UK, European Centre for Disease Prevention and Control, 2020

36. European Coordination Via Campesina, Sowing Injustice, Harvesting Despair; The Role of Intermediation Schemes abuse And Exploitation of Foreign Agricultural Workers, Spain, 2019

37. The Transformation of Agri-Food Systems, Globalization, Supply Chains and Small holder Farmers, McCullough, E. B. et al. (eds.), The Food and Agriculture Organization of the United Nations and Earthscan, London, 2008

38. Töttös, A., The Past, the Present and the Future of the Seasonal Workers Directive, Pécs Journal of International and European Law, Vol. 45, No. 1, 2014, p. 45-60

39. Williams, C.; Horodnic, A., Tackling undeclared work in the agricultural sector, European Platform Undeclared Work, 2018

40. Zawojska, A., Exploitation of migrant labour force in the EU agriculture, Scientific Journals of the Warsaw University of Life Sciences, Economics and Organization of Food Economy, No. 116, 2016, p. 37-55 
41. Zilli, A., L'inclusione sociale attraverso i voucher per prestazioni di lavoro accessorio, in Brollo, M.; Cester; C.; Menghini, L. (eds.), Legalità e rapporti di lavoro: Incentivi e sanzioni (Trieste, EUT, 2016).

42. Zoeteweij, M. H., The Seasonal Workers Directive Another Vicious Circle? in: Rijken, C.; de Lange, T. (eds.), Towards a Decent Labour Market for Waged Migrants Workers, Amsterdam University Press, Amsterdam, 2018, p. 129-148

\section{EU LAW}

1. Directive 2014/36/EU of the European Parliament and of the Council of 26 February 2014 on the conditions of entry and stay of third-country nationals for the purpose of employment as seasonal workers [2014], OJ L 94, 28.5.2014

2. European Commission (2010), Commission Staff Working Document: Summary of Impact Assessment accompanying the proposal for a Directive of the European Parliament and of the Council on the conditions and entry of third-country nationals for the purpose of seasonal employment. COM (2010) 379 final, SEC (2010) 887', in Commission, E. (ed). Brussels

3. European Commission (2014), Communication from the Commission to the European Parliament and the Council on the application of Directive 2009/52/EC of 18 June 2009 providing for minimum standards on sanctions and measures against employers of illegallystaying third country nationals, COM (2014) 286 final, 22.5.2014

4. European migration network, (2020), Attracting and protecting the rights of sasonal workers in the EU and United Kingdom, European Migration Network (EMN), Brussels, 2020

5. European Commission, Kalantaryan, S. et al., Meeting labour demand in agriculture in times of COVID 19 pandemic, 2020

6. European Commission, Muñoz de Bustillo Llorente, R., Pinto Hernández, F., Reducing Precarious Work in Europe Through Social Dialogue: The Case of Spain, University of Salamanca, Spain, 2017

7. European Pillar of Social Rights, Fair working conditions, Secure and adaptable employment, 2017

\section{ILO DOCUMENTS}

1. ILO (2007), Agricultural Workers and Their Contribution to Sustainable Agriculture and Rural Development, Switzerland, 2007

2. ILO (2019), Decent and Productive Work in Agriculture, International Labour Office, Geneva, 2019

3. ILO (2014), Fair migration: Setting an ILO agenda, International Labour Office, Geneva, 2014

4. ILO (2016a), Non-standard employment around the world: Understanding challenges, shaping, International Labour Office, Geneva, 2016

5. ILO (2016), Non-standard forms of Employment around the world, International Labour Office, Geneva, 2016 
6. ILO (2020a), Seasonal Migrant Workers' Schemes: Rethinking Fundamental Principles and Mechanisms in light of COVID-19, International Labour Office, Geneva, 2020

7. ILO, The Safety and Health in Agricultural Convention (No. 184), 2001

8. ILOSTAT, Employment by sex and economic activity - ILO modelled estimates, November 2019

\section{LIST OF NATIONAL REGULATIONS, ACTS AND COURT DECISIONS}

1. Act on Civil Procedure (Zakon o parničnom postupku), Official Gazette No. 148/2011, 25/2013, 89/2014, 70/2019

2. Aliens Act (Zakon o strancima, 2011), Official Gazette No. 130/2011, 74/2013, 69/2017, 46/2018, 66/2019, 53/2020, 133/2020

3. Aliens Act (Zakon o strancima, 2021), Official Gazette No. 133/20

4. Compulsory Health Insurance Act (Zakon o obveznom zdravstvenom osiguranju), Official Gazette No. 80/2013, 137/2013, 98/2019

5. Health Protection Act (Zakon o zdravstvenoj zaštiti), Official Gazette No. 100/2018, $125 / 2019,133 / 2020,147 / 2020$

6. Labour Act (Zakon o radu, 2010), Official Gazette No. 149/2009, 61/2011, 82/2012, $73 / 2013$

7. Labour Act (Zakon o radu, 2014), Official Gazette No. 93/2014, 127/2017, 98/2019

8. Labour Market Act (Zakon o tržištu rada), Official Gazette No. 118/2018, 32/2020

9. Zakon o zaštiti na radu (Occupational Health and Safety Act), Official Gazette No. 71/2014, $118 / 2014,154 / 2014,94 / 2018,96 / 2018)$

10. Odluka o utvrđivanju godišnje kvote dozvola za zapošljavanje stranaca za kalendarsku godinu 2020., Official Gazette No. 113/2019.

11. Pravilnik o sadržaju i obliku ugovora o sezonskom radu u poljoprivredi, Official Gazette No. 28/2019

12. Pravilnik o statusu i radu državljana trećih zemalja u Republici Hrvatskoj, Official Gazette No. 52/2012, 81/2013, 38/2015, 100/2017, 61/2018, 116/2018, 133/2020, 146/2020

\section{WEBSITE REFERENCES}

1. Afsar, N.; Antoons, J., Seasonal workers in Belgium, EMN, 2021, p. 19, [https://emnbelgium.be/sites/default/files/publications/Seasonal_workers_standalone.pdf], Accessed 24 February 2021

2. Agricultural workers' rights abuses in Spain. [https://www.ethicalconsumer.org/food-drink/ agricultural-workers-rights-abuses-spain], Accessed 23 March 2021

3. Covid19: Food \& vital supplies for migrant workers [https://www.crowdfunder.co.uk/supportworkers], Accessed 13 April 2021

4. Croatian Chamber of Commerce. [https://www.hgk.hr/vanjskotrgovinski-deficit-poljoprivrednih-i-prehrambenih-proizvoda-smanjen-za-315-posto], Accessed 18 October 2020 
5. EU Agency for Fundamental Rights, Coronavirus COVID-19 outbreak in the EU Fundamental Rights Implications, 2020, [https://fra.europa.eu/sites/default/files/fra_uploads/ malta-report-covid-19-april-2020_en.pdf], Accessed 12 December 2020

6. EMN, Attracting and protecting, Czech Republic, 2020, p. 16. [https://ec.europa.eu/homeaffairs/sites/default/files/06_czechrep_seasonal_workers_2020_en.pdf], Accessed 21 March 2021

7. Eurofound (2020a) Minimum wages in 2020: Will COVID-19 derail the quest for fair pay? 2020 https://www.eurofound.europa.eu/hr/publications/blog/minimum-wages-in2020-will-covid-19-derail-the-quest-for-fair-pay], Accessed 23 March 2021

8. Eurofound, Italy: New voucher-based work scheme provokes debate, 2017. [https://www.eurofound.europa.eu/publications/article/2017/italy-new-voucher-based-work-scheme-provokes-debate], Accessed 23 March 2021

9. Eurofound, Living and Working in Italy, 2021, [https://www.eurofound.europa.eu/hr/country/italy], Accessed 11 January 2021

10. European Commission, Migration and Home Affairs [https://ec.europa.eu/home-affairs/ what-we-do/policies/legal-migration/work_en], Accessed 23April 2021

11. European Labour Authority, Safeguarding seasonal workers' rights: European Labour Authority takes action, 2019 [https://www.ela.europa.eu/news/safeguarding-seasonal-workers-rightseuropean-labour-authority-takes-action], Accessed 6 December 2020

12. European Pillar of Social Rights, [https://eur-lex.europa.eu/legal-content/EN/TXT/?uri=C ELEX\%3A32017C1213\%2801\%29], Accessed 12 January 2021

13. European Parliament Resolution of 19 June 2020 on European protection of cross-border and seasonal workers in the context of the COVID-19 crisis, [https://www.europarl.europa. eu/doceo/document/TA-9-2020-0176_EN.html], Accessed 1 March 2021

14. FAO, Sustainable Development Goals, 2015, [http://www.fao.org/sustainable-developmentgoals/overview/fao-and-the-post-2015-development-agenda/sustainable-agriculture/en/], Accessed 2 February 2021

15. Germany - important information for seasonal worker, 2020 [https:/www.arbeitsagentur. de/datei/important-information-for-seasonal-workers_ba146928.pdf ], Accessed 11 January 2021

16. Germany: 1,500 workers test positive for COVID-19 at meat-processing plant; company criticised for "failure" to protect workers. Business \& Human Rights Resource Centre. [https://www.business-humanrights.org/en/latest-news/germany-1500-workers-test-positive-for-covid-19-at-meat-processing-plant-company-criticised-for-failure-to-protect-workers/], Accessed 2 April, 2021

17. Hrvatski zavod za zapošljavanje, Vladine mjere za očuvanje radnih mjesta, [https://mjeraorm.hzz.hr/ocuvanje-radnih-mjesta/], Accessed 2 May 2021

18. Hrvatski zavod za zdravstveno osiguranje [https://www.hzzo.hr/en/prava-osiguranika-naprivremenu-nesposobnost-za-rad-zbog-pojave-koronavirusa-2019ncov/], Accessed 2 February 2021

19. Info za članove hup-a: isplate potpore hzz-a za travanj i svibanj [https://www.hup.hr/infoza-clanove-hup-a-isplate-potpore-hzz-a-za-travanj-i-svibanj.aspx], Accessed 28 April 2021 
20. Initiative Faire Landarbeit (2020), Saisonsarbeit in der Landwirtschaft NP [https://www. pecoev.de/docs/InitiativeFaireLandarbeit_Bericht2020_IGBAU-neu.pdf], Accessed 13 January 2021

21. Izvješće pučke pravobraniteljice za 2020 godinu, [https://www.ombudsman.hr/hr/download/izvjesce-pucke-pravobraniteljice-za-2020-godinu/?wpdmdl=10845\&refresh=608e7e9 57ab3e1619951253], Accessed 24 April 2021

22. Labour Law and Employment in Hungary - 2021 Guide, [https://accace.com/labour-lawand-employment-in-hungary/], Accessed 2 February 2021

23. Nacrt prijedloga Strategije poljoprivrede do 2030., [https://poljoprivreda.gov.hr/UserDocsImages/dokumenti/Strategija_poljoprivrede_2020_2030/Strategija_poljoprivrede_ do_2030..pdf], Accessed 2 May 2021

24. New measures to preserve jobs in Croatia COVID [https://www.cms-lawnow.com/ ealerts/2020/10/new-measures-to-preserve-jobs-in-croatia?cc_lang=en], Accessed 25 April 2021

25. Report on the situation at Manolada, 2020, [https://g2red.org/report-on-the-situation-atmanolada-july-2020], Accessed 2 February 2021

26. Seasonal Workers from Third Countries in Austria, UN Migration, 2020, [https://www. emn.at/wp-content/uploads/2020/11/emn-national-report-2020-seasonal-workers-in-at. pdf], Accessed 17 April 2021

27. Smarter, Nezaposlene potrebno motivirati za sezonski rad u poljoprivredi, 2020, [https://smarter.hr/nezaposlene-potrebno-motivirati-za-sezonski-rad-u-poljoprivredi/], Accessed 7 March 2021

28. Vidas, I., Pravni aspekt ograničenja prava radnika u slučaju pandemije s posebnim naglaskom na prava $i$ obveze poslodavaca i radnika, IUS-INFO, 86/2020, [https://www.iusinfo.hr/ aktualno/u-sredistu/41010], Accessed 3 May 2021

29. Vlada Republike Hrvatske, Službena stranica Vlade za pravodobne i točne informacije o koronavirusu,[https://www.koronavirus.hr/rezultatipretrazivanja/20?q=vladine+mjere\#gsc. tab=0\&gsc.q=vladine\%20mjere\&gsc.page=1], Accessed 25 April 2021 